ROCZNIKI HUMANISTYCZNE

Volume 67, issue 1 - 2019

SELECTED PAPERS IN ENGLISH

DOI: http://dx.doi.org/10.18290/rh.2019.67.1-2en

\title{
DIRK UFFELMANN
}

\section{HERBERT'S POSTCOLONIAL ANTIQUITY AND DEFENSIVE NATIONALISM}

\section{POSTCOLONIAL ANTIQUITY}

Antiquity and postcolonialism-can they work together? A first tentative answer might be given on the ground of Zbigniew Herbert's poem "Przemiany Liwiusza" ("Transformations of Livy," 1990): the poem's speaker reads the Roman model historian Titus Livy in a deconstructive manner, against the grain of Livy's apology of Roman imperialism, ${ }^{1}$ as it was taught in a classical-language high school in Herbert's home city Lwów (Lemberg):

więc za Liwiuszem wpajał [łacinnik] w uczniów pogardę dla motłochu / bunt ludu - res tam foeda - budził w nich odrazę / natomiast wszystkie podboje wydawały się słuszne / znaczyły po prostu zwycięstwo tego co lepsze silniejsze

so following Livy he [the teacher of Latin] implanted in his pupils the contempt for the mob / the revolt of the people_res tam foeda - aroused loathing in them / whereas all of the conquests appeared just / they showed simply the victory of what is better stronger ${ }^{2}$

Prof. DiRk Uffelmann-Justus Liebig University Giessen, FB05, Department of Slavic Languages and Literatures, Professor of East and West Slavic Literatures; e-mail: dirk.uffelmann@ slavistik.uni-giessen.de

The Polish version of this article was published in Roczniki Humanistyczne vol. 65, issue 1 (2017).

${ }^{1}$ Cf. Marek ADAMIEC, “Pomnik trochę niezupetny...” Rzecz o apokryfach i poezji Zbigniewa Herberta (Gdańsk: Wydawnictwo Uniwersytetu Gdańskiego, 1996), 54-55.

${ }^{2}$ Zbigniew Herbert, Poezje wybrane / Selected Poems, trans. John and Bogdana Carpenter, Czesław Miłosz, and Peter Dale Scott (Kraków: Wydawnictwo Literackie, 1999), 159, trans. John and Bogdana Carpenter. I will further use underlining to stress grammatical phenomena without each time pointing to the fact that the underlining stems from me. In contrast, semantic emphases are marked by italics. 
$19^{\text {th }}$-century classical-language pedagogy aimed at the pupils' identification with imperialists. Both the speaker's grandfather and great-grandfather succumbed to it:

Czytając dzieje Miasta ulegali złudzeniu / że są Rzymianami lub potomkami Rzymian / ci synowie podbitych sami ujarzmieni

Reading the history of the City they surrendered to the illusion / that they are Romans or descendants of the Romans / these sons of the conquered themselves enslaved $^{3}$

Against this grain, thus Herbert's poem, the positionality of the "conquered" and "enslaved" in post-partition Poland should rather suggest another identification, with the forgotten victims ${ }^{4}$ of Roman colonization:

\author{
owych Hirpinów Apulów Lukanów Uzentyńczyków / a także mieszkańców \\ Tarentu Metapontu Lokri \\ those Hirpins Apuleans Lucanians Osunans / also the inhabitants of Tarentum \\ Metapontis Locri $^{5}$
}

In 1990, when the poem was written and the end of the Eastern bloc and of Soviet domination in Eastern Europe loomed ahead, the speaker confronts Livy's and classical-language apology of colonization and imperialism with an anticipation of the future:

Mój ojciec wiedział dobrze i ja także wiem / że któregoś dnia $[\ldots] / /[\ldots]$ runie
imperium
My father knew well and I also know / that one day on $[\ldots] / /[\ldots]$ the empire will fall ${ }^{6}$

With this shift to a post-imperial future the speaker adopts a postcolonial axiological perspective-against imperialism and colonialism and in favor of their victims. The question of whether Zbigniew Herbert had the chance

\footnotetext{
${ }^{3}$ Herbert, Poezje wybrane / Selected poems, 159, trans. John and Bogdana Carpenter.

${ }^{4}$ This goes in line with the allusion to Isaiah 53,3 "res tam foeda," one of the passages of the Old Testament which used to be interpreted in a typological way with reference to Jesus Christ. This Christological hint refers to another tradition of the $19^{\text {th }}$ century: the designation of Poland as "Christ of the peoples" in the wake of Adam Mickiewicz's "Księgi narodu polskiego i pielgrzymstwa polskiego" ("The Books and The Pilgrimage of the Polish Nation," 1832).

${ }^{5}$ Herbert, Poezje wybrane / Selected Poems, 161, trans. John and Bogdana Carpenter.

${ }^{6}$ Ibidem.
} 
to come across Jacques Derrida's deconstructive reading strategies or Edward Said's critique of Orientalism in Paris before 1990 need not be answered here. Beyond doubt is the textual finding that Herbert's reading of Livy from 1990 can be called postcolonial; his revision of Livy can clearly be understood as Writing Back in the sense of Ashcroft, Griffiths, and Tiffin. ${ }^{7}$

But what happens with postcolonial heuristics when they are not applied to modernity but to premodern conditions, ${ }^{8}$ in this case to antiquity? Here is not the place to discuss the productivity of postcolonial approaches to Roman colonial history. ${ }^{9}$ I rather endeavor the interpretation of Herbert's specific oscillation between the legacy of antiquity on the one hand, and Polish history and present on the other, against the backdrop of existing postcolonial approaches to Polish studies.

\section{2. "WHY THE CLASSICS?"}

As is well known, the purpose of allusions to the present inherent in his multifold references to antiquity was thematized by Zbigniew Herbert himself in the very title of his Thucydides poem "Dlaczego klasycy" ("Why the Classics?" 1969). The poem, however, provides a very reluctant answer or non-answer. Nevertheless, Julian Kornhauser is erroneous with his 1974

\footnotetext{
${ }^{7}$ Bill Ashcroft, Gareth Griffiths, Helen Tiffin, The Empire Writes Back: Theory and Practice in Post-Colonial Literatures (London, New York: Routledge, 1989).

${ }^{8}$ This goes for Maria Janion's anti-Catholic postcolonial analysis of the Christianization of the ancient Slavs (Maria JANION, Niesamowita stowiańszczyzna, Kraków 2007) for which she was attacked from a Catholic-postcolonial perspective, see: Dariusz SKóRCZEWSKI, Teoria-literatura —dyskurs. Pejzaż postkolonialny (Lublin: Wydawnictwo KUL, 2013), 407-425.

${ }^{9}$ Cf., for example: Roman Imperialism: Post-Colonial Perspectives. Proceedings of a Symposium Held at Leicester University in November 1994, ed. Jane Webster, Nicolas J. Cooper, Leicester: University of Leicester 1996; Peter A.R. van Dommelen, On Colonial Grounds: A Comparative Study of Colonialism and Rural Settlement in First Millennium BC West Central Sardinia (Leiden: Faculty of Archaeology, University of Leiden, 1998); Nicola TerRenato, "The Deceptive Archetype: Roman Colonialism in Italy and Postcolonial Thought," in Ancient Colonizations: Analogy, Similarity and Difference, ed. Henry Hurst, Sandra Owen (London: Duckworth, 2005), 59-72; David J. Mattingly, Imperialism, Power, and Identity: Experiencing the Roman Empire (Princeton (NJ), Oxford: Princeton University Press, 2011); Richard Hingley, "Post-Colonial and Global Rome: The Genealogy of Empire," in Globalisation and the Roman World: World History, Connectivity and Material Culture, ed. Martin Pitts, Miguel John Versluys (Cambridge: Cambridge University Press 2015), 32-46.
} 
thesis concerning the apoliticality of Herbert's revocations of antiquity. ${ }^{10}$ Rather, Stanisław Barańczak is right in saying:

[...] sensy polityczne [...] trzeba przy czytaniu poezji Herberta brać między innymi pod uwagę.

$[\ldots]$ the political meanings $[\ldots]$ must be taken into account among others while reading Herbert's poetry.

In Herbert's most authoritative poem ${ }^{12}$ "Przesłanie Pana Cogito" ("The Envoy of Mr Cogito," 1974), for example, the speaker's political sensitivity is-comparably to "Przemiany Liwiusza"- directed toward those defeated and killed:

Powtarzaj stare zaklęcia ludzkości bajki i legendy / [...] / powtarzaj wielkie słowa powtarzaj je z uporem / jak ci co szli przez pustynię i ginęli w piasku

Repeat old incantations of humanity fables and legends / [...] / repeat great words repeat them stubbornly / like those crossing the desert who perished in the sand ${ }^{13}$

Heroic losers function as models of morality:

idź bo tylko tak będziesz przyjęty do grona zimnych czaszek / do grona twoich przodków: Gilgamesza Hektora Rolanda

go because only in this way will you be admitted to the company of cold skulls / to the company of your ancestors: Gilgamesh Hector Roland ${ }^{14}$

${ }^{10}$ Julian KORNHAUSER, "Herbert: z odległej prowincji," in Julian KORNHAUSER, Adam ZAGAJEWSKI, Świat nie przedstawiony (Kraków: Wydawnictwo Literackie, 1974), 100-109; Stanisław BARAŃCZAK, Uciekinier z utopii. O poezji Zbigniewa Herberta (London: Polonia, 1984), 12.

${ }^{11}$ BARAŃCZAK, Uciekinier z utopii, 12: emphasis in the original. Cf. also Ulrich Schmid's reconstruction of the political interventions (and personal foibles) of the citizen Zbigniew Herbert: Ulrich SCHMID, "Nach dem Kommunismus. Herberts politische Interventionen in der Dritten Republik, in Herr Cogito im Garten. Zbigniew Herbert, ed. Andreas Lawaty, Piotr Przybyła, Marek Zybura (Osnabrück: Fibre, 2018), 191-200.

${ }^{12}$ Cf. Andrzej KowalczyK, "Złote runo nicości," in Tygodnik Powszechny no 11 (1983): 4; Andrzej Kaliszewski, Gry Pana Cogito (Łódź: Wydawnictwo Łódzkie, 1990), 210; Dirk UfFelMANN, “Autobiografizm i antropologia. 'Ecce homo' F. Nietzschego i 'Pan Cogito' Z. Herberta," in Postać literacka, ed. Edward Kasperski, Brygida Pawłowska-Jądrzyk (Warszawa: Uniwersytet Warszawski, 1998), 53-75, here pp. 70-72; Jan BigAJ, "Za przesłaniem Herberta nie pójdę," in Herbert. Poetyka, wartości i konteksty, ed. Eugeniusz Czaplejewicz, Witold Sadowski (Warszawa: Wydawnictwo DiG, 2002), 165-172.

${ }^{13}$ Herbert, Poezje wybrane / Selected Poems, 97, trans. John and Bogdana Carpenter.

${ }^{14}$ Ibidem, cf. Jacek ŁuKASIEwICZ, Poezja Zbigniewa Herberta (Warszawa: Wydawnictwa Szkolne i pedagogiczne, 1995), 80. 
Even if the transhistorical panoramas evoked by Herbert's speakers include events from Polish history, they are regularly about defensive attitudes and defeats, e.g. in "Raport z oblężonego miasta" ("Report from the Besieged City," 1983):

[...] nie wiem kiedy zaczął się najazd / przed dwustu laty w grudniu wrześniu może wczoraj o świcie / wszyscy chorują tutaj na zanik poczucia czasu

[...] I don't know when the invasion began / two hundred years ago in December in September perhaps yesterday at dawn / everyone here suffers from a loss of the sense of time ${ }^{15}$

This poem draws a line from the partitions of Poland at the end of the $18^{\text {th }}$ century to the revolt of December 1970, and another one from the quick military defeat at the beginning of World War Two in September 1939 to the declaration of martial law in 1981. Brief allusions are sufficient for Polish contemporary readers; the historical traumas need only be briefly touched upon and for Polish long-term memory-thus the poem's suggestionconsensus is immediately achieved: external violence penetrates the Polish inner world; it has always been like this, in the present of the Polish People's Republic from Soviet Russia; this is what Herbert insinuates in "Potęga smaku" ("The Power of Taste," 1983):

samogonny Mefisto w leninowskiej kurtce / posyłał w teren wnuczęta Aurory

a home-brewed Mephisto in a Lenin jacket / sent Aurora's grandchildren out into the field ${ }^{16}$

In the inner world there arises the question of how to deal with the cultural repercussions of such an imposed colonization-via subjugation and thus betrayal or by esthetic resistance? Herbert's speaker leaves no doubt that the latter is imperative:

To wcale nie wymagało wielkiego charakteru / nasza odmowa niezgoda i upór / mieliśmy odrobinę koniecznej odwagi

It didn't require great character at all / our refusal disagreement and resistance / we had a shred of necessary courage ${ }^{17}$

\footnotetext{
${ }^{15}$ Herbert, Poezje wybrane / Selected Poems, 149, trans. John and Bogdana Carpenter.

${ }^{16}$ Ibidem, 145.

${ }^{17}$ Ibidem.
} 
The colonization of Polish political culture ("Lenin jacket"), externally induced by the October Revolution ("Aurora"), must be met with a collective refusal from the national community ("nasza odmowa").

\section{DEFENSIVE NATIONALISM}

Does the binary of external colonial violence and collective resistance in the inner sphere make Herbert a defensive, even a nationalist poet? To read him like this may seem almost like blasphemy for Herbert philologists, who have long been accustomed to working with high moral identification. An important impulse for such a research question is provided by Piotr Lachmann; in my heuristics of a structurally nationalist thinking palpable in Herbert's poems, I refer to Lachmann's evaluation: ${ }^{18}$

[...] bywają poeci pochyleni nad losem swojej jednoznacznej Ojczyzny. Nie należę do nich, ale nie smuci mnie ten fakt. [...] Najłatwiej jest tym, którzy artykułują "zbiorowe tęsknoty", którzy w swoich wierszach wypowiadają "zbiorowe traumata". Pod tym względem Herbert [...] był—-wzorem, tyle że nie do naśladowania dla mnie. ${ }^{19}$

[...] there are poets who continuously bow their head over the fate of their unambiguous fatherland. I do not belong to them, this does not concern me. [...] It is easiest for those who articulate "collective strivings," who in their poems express "collective traumas." In this respect Herbert was exemplary, only not for me to imitate $[\ldots]$.

Can Lachmann's claim that Herbert is "exemplary" in articulating "collective traumas" be validated based on his poems? At first glance Herbert's meta-political poem "Rozważania o problemie narodu" ("Reflections on the Problem of the Nation," 1961) seems to refute this assumption since it demonstrates the negative effects of xenophobic nationalism:

[...] wspólna lektura szkolna / nie powinna stanowić przesłanki wystarczającej / aby zabić

[...] nor should any shared school syllabus / become a premise sufficient / for killing 20

\footnotetext{
${ }^{18}$ I owe this hint to Stefan Chwin.

${ }^{19}$ Piotr LaCHMAnN, Wywołane z pamięci (Olsztyn: Wspólnota Kulturowa "Borussia," 1999), 67.

${ }^{20}$ Zbigniew Herbert, Studium przedmiotu (Wrocław: Wydawnictwo Dolnośląskie, 1997), 47; Zbigniew Herbert, The Collected Poems 1956-1998, ed. Alissa Valles (New York: Ecco,
} 
On the other hand, the speaker advocates what in the theory of nationalism is called the "primordialist" presupposition of the nation as something given (and not constructed): "stwierdzam tylko / istnienie tego związku" ("I only ascertain / the existence of such a connection"). ${ }^{21}$ Both statements can be linked to Lachmann's assumption of Herbert articulating "collective traumas." Circulating about the national collective need not necessarily immunize the former against external critique; it suffices if it constructs it as a community of victims:

In what follows I intend to demonstrate that in the case of Herbert's poetry, the traumatic genealogy of the community of victims points in the direction of a combined double defense - a defense against external influences and incursions of an inimical system against the people depicted as victims.

In a system imposed from outside such as the Polish People's Republic the external and internal villains, against whom the nation or the individual are put in a defensive position, interweave. Thus, my thesis is that Lachmann is partially right and that Herbert's poetry from the times of the People's Republic can indeed be described as a postcolonial variety of defensive nationalism, situated at the political right, as it became politically dominant in Poland in the 2010s. ${ }^{22}$ In the middle period of Herbert's lyrical work, in the 1970s and 80s, motifs taken from antiquity in a broader senseincluding history, ancient polytheisms, but also biblical subjects ${ }^{23}$ - function

2007), 189, trans. Alissa Valles; cf. also Adam Michniк, "Potęga smaku," in $Z$ dziejów honoru $w$ Polsce (Paris: Instytut Literacki, 1985), 199-280, here p. 266.

${ }^{21}$ HerberT, Studium przedmiotu, 47-48.

${ }^{22}$ It comes not by chance that Ewa Thompson, to whose view of Poland as a victim of colonization I refer as a heuristic parallel to Herbert, positively identifies with defensive nationalism: "Defensive nationalism characterizes those 'memory communities' which perceive themselves as being at risk, either because of their smallness (Lithuanians, Georgians, Chechens) or because their expansionist neighbors have threatened them. [...] Defensive nationalism is a means of resisting the encroachment of the hostile Other upon one's identity [...]" See: Ewa M. Thompson, "Nationalism, Imperialism, Identity: Second Thoughts," in Modern Age 40, no 3 (1998): 250-261, here p. 256.

${ }^{23}$ The extension of this term in my use coincides with Bogdan Trocha's diagnosis of Herbert's mythopoiesis: Bogdan TROCHA, "Mythopoeiczne aspekty liryki Zbigniewa Herberta," in Pojęcia kietkujące z rzeczy. Filozoficzne inspiracje twórczości Zbigniewa Herberta, ed. Józef Maria Ruszar (Kraków: Wydawnictwo Platan, 2010), 101-137, here p. 103. What is more, for me the occurrence of isolated motifs of antiquity suffices as a criterion for including a poem in my analysis; in Herbert's poetry consistent historical and mythological settings are rare anyway, so there is no plausible quantitative criterion which would allow for failing to take into account the sporadic allusions to antiquity in Herbert's allegedly most "presentist" political poem, "Raport z oblężonego miasta" ("Report from the Besieged City," in Herbert, Poezje wybrane / Selected 
as allegories for internal political phenomena of the Polish People's Republic, which appear to him as an external-internal colonization of Poland's political culture. $^{24}$

The traumatized victims of such an external-internal colonization of political culture need not necessarily be a collective in Herbert's poetic depiction - and not one that is to be recognized immediately as the Polish national community. Lachmann's claim of the collectivity of the national subject in Herbert must therefore be checked both with regard to the identification of the victims as Polish and concerning the grammatical prism which I direct to Herbert's poetry (a kind of "grammar of poetry" in the sense of Roman Jakobson): I scrutinize the way in which Herbert's poetry uses the numeri of appellatives and pronouns ${ }^{25}$ in contexts where they refer to the execution of power. On the side of rulers and perpetrators in general, ethnonyms and names for professional groups are more relevant than individual tyrants, which can be deciphered allegorically, in order to determine the occurrence or non-occurrence of xenophobic nationalism. On the other hand, when it comes to the victims, we have to distinguish the collective plural of a national "we" group from universal exemplary individuals (Herbert's famous "Mr Cogito").

Given this double scope, I propose to at least partially "ground" Herbert's antiquity allegories with the help of grammar, despite their strategic and irreducible suspension between politics and universalism. This structuralist partial move in the direction of an objective science of literature that I perform by this, however, serves the goal of a hermeneutic reading of Herbert's poems from a postcolonial perspective and with the help of contextualization.

Poems, trans. John and Bogdana Carpenter), such as "ruiny świątyń" ("the ruins of temples," 149), "Goci" ("Goths," 151) or even the metaphor of siege which stems from premodern military technique as well.

${ }^{24}$ For the occasional occurrence of the word "colonization" in Herbert, see: Jens HerLth, "Wer sind Herberts Barbaren?" in Herr Cogito im Garten. Zbigniew Herbert, ed. Andreas Lawaty, Piotr Przybyła, Marek Zybura (Osnabrück: Fibre, 2018), 135-151, here p. 140.

${ }^{25}$ In his articles "Поэзия грамматики и грамматика поэзии" and "Poetry of Grammar and Grammar of Poetry" Roman Jakobson, among others, stresses the significance of numeri, appellatives, and pronouns for a "grammar of poetry," see: Roman JAKOBSON, "Poeziia grammatiki i grammatika poezii," in Selected Writings. Vol. 3 (The Hague, Paris: Mouton, 1980), 63-86, here p. 71; Roman JAKOBSON, "Poetry of Grammar and Grammar of Poetry," in Selected Writings, Vol. 3, 87-97, here p. 93). I combine these grammatical prisms, asking for the numeri of appellatives applied by Herbert for perpetration and victimization and for the numeri of pronouns presenting nations or individuals. 


\title{
4. PERPETRATORS AND VICTIMS IN THE SINGULAR
}

Herbert's antiquity poems often present groups of perpetrators in the plural: it is "they" who kill, like in "Anabaza" ("Anabasis"):

\author{
Kondotierzy Cyrusa legia cudzoziemska / [...] mordowali / [...] / na szczęście nie \\ kłamali że bronią cywilizacji \\ The condottieri of Cyrus the Foreign Legion / [...] murdered / [...] / it's good they \\ didn't claim to be defending civilization ${ }^{26}$
}

It is equally "they" who misuse power for the sake of tyranny: "generałowie / atleci władzy / despoci" ("generals / power brokers / despots") ${ }^{27}$ ); "they" who spy or execute: "Pogarda / dla szpiclów katów tchórzy" ("Scorn / for the informers executioners cowards") ${ }^{28}$; "they" who persecute the speaker: "o moich wodnistookich szarych niemądrych prześladowcach" ("of my moist-eyed gray deluded persecutors") ${ }^{29}$; finally "they" who apply the impoverished language of propaganda:

\footnotetext{
Zaiste ich retoryka była aż nazbyt parciana / (Marek Tulliusz obracał się w grobie) / łańcuchy tautologii parę pojęć jak cepy / dialektyka oprawców żadnej dystynkcji w rozumowaniu / składnia pozbawiona urody koniunktiwu

Verily their rhetoric was made of cheap sacking / (Marcus Tullius kept turning in his grave) / chains of tautologies a couple of concepts like flails / the dialectics of slaughterers no distinctions in reasoning / syntax deprived of beauty of the subjunctive $\mathrm{e}^{30}$
}

The grammatical plural, as it is used either for professionally defined adversaries or for enemies epitomized with the personal pronoun "them," does not change even with regard to single addressees such as Ryszard Krynicki in "Do Ryszarda Krynickiego-list” (“To Ryszard Krynicki-A Letter”):

\footnotetext{
${ }^{26}$ Zbigniew HERBERT, Raport z oblężonego miasta (Wrocław: Wydawnictwo Dolnośląskie, 1995), 62; Zbigniew Herbert, The Collected Poems 1956-1998, 382, trans. Alissa Valles.

27 "O cnocie" ("Mr Cogito on Virtue"), in Zbigniew Herbert, Poezje / Gedichte, ed. Karl Dedecius (Kraków: Wydawnictwo Literackie, 2007), 120-121; Zbigniew HerberT, The Collected Poems 1956-1998, 361, trans. Alissa Valles.

28 "Przesłanie Pana Cogito" ("The Envoy of Mr Cogito)," in Herbert, Poezje wybrane / Selected Poems, 95, trans. John and Bogdana Carpenter.

29 "Modlitwa Pana Cogito-podróżnika" ("Prayer of the Traveler Mr Cogito"), in HerberT, Poezje / Gedichte, 106-107; Zbigniew Herbert, The Collected Poems 1956-1998, 348, trans. Alissa Valles.

30 "Potęga smaku" ("The Power of Taste)," in Herbert, Poezje wybrane / Selected Poems, 145, trans. John and Bogdana Carpenter.
} 
[...] przeciwników [...] mieliśmy nikczemnie małych

$[\ldots]$ we had opponents despicably small ${ }^{31}$

An exception from this tendency toward referring to perpetrators in the plural are divine perpetrators of violence such as Apollo, for example in "Apollo i Marsjasz" ("Apollo and Marsyas") with his individual victim Marsyas, or the eponymous protagonists of poems about tyrannical Roman emperors such as "Kaligula" ("Caligula") and "Boski Klaudiusz" ("The Divine Claudius"). Herbert imbues those called by name with an ironic psychology of tyranny and terror, which among others can be read as a reference to Iosif Stalin.

The losers and victims appear in the plural less often. To be sure, Herbert applies the plural regarding Native Americans " $\underline{\mathrm{Ci}}$ którzy przegrali" ("They Who Lost") ${ }^{32}$ or the slaves of Diocletian:

Tylko nigdy nie domyśli się [Cyceron], że żyłki marmuru w termach Dioklecjana to są pęknięte naczynia krwionośne niewolników z kamieniołomów.

Only he never figures out that the veins in the marble of Diocletian's baths are the burst blood vessels of slaves from the stone quarries. ${ }^{33}$

The Polish national metonymy par excellence, the Wawel hill in Krakow, is also presented as a collective "Akropol dla wydziedziczonych" ("An Acropolis for the dispossessed"). ${ }^{34}$

More often Herbert asyndetically enumerates individual losers such as "Gilgamesz Hektor Roland" or "Roland[] Feliksiak[] Hannibal[l" ("Roland Kowalski Hannibal"). ${ }^{35}$ Most important in his poems, however, are singular protagonists with whom Herbert's archetypical thinking subject $\mathrm{Mr} \mathrm{Cogito}^{36}$

31 “To Ryszard Krynicki-A Letter," in Herbert, Poezje wybrane / Selected Poems, 113, trans. John and Bogdana Carpenter.

32 Herbert, Poezje / Gedichte, 66-67; Herbert, The Collected Poems 1956-1998, 297, trans. Alissa Valles.

33 "Klasyk" ("Classic”), in Zbigniew HeRBert, Wiersze zebrane, ed. Ryszard Krynicki (Kraków: Wydawnictwo a5, 2008), 205; Herbert, The Collected Poems 1956-1998, 141, trans. Alissa Valles. Paradoxically, this history focused on the victims sounds very much reminiscent of communist historiography, for example about the Petrine Reforms.

34 "Wawel," in Zbigniew Herbert, Struna światta (Wrocław: Wydawnictwo Dolnośląskie, 1994), 67; HerberT, The Collected Poems 1956-1998, 44, trans. Alissa Valles.

35 "Deszcz" ("The Rain"), in Herbert, Wiersze zebrane, 119; IDEM, The Collected Poems 1956-1998, 90, trans. Alissa Valles.

${ }^{36}$ Vgl. Ryszard PRZYBYLSKI, "Między cierpieniem a formą," in IDEM, To jest klasycyzm (Warszawa: Czytelnik, 1978), 124-175, here p. 149. 
identifies, e.g. Cato the Younger in "Pan Cogito o postawie wyprostowanej" ("Mr Cogito on Upright Attitudes"). The social isolation of this exemplary subject, which hardly ever engages in a dialogue with a living counterpart, may be evaluated as a political-cultural effect of totalitarianism (like it seemed to Adam Michnik while he was incarcerated in the prison of Mokotów ${ }^{37}$ ), but a coordination of the single victim with a "collective trauma" in the sense of Lachmann hardly takes place here. The prosopopoeia of $\mathrm{Mr}$ Cogito rather points in the direction of a universal philosophical anthropology.

Does this tendency toward universalization refer to collective victims as well? The existing interpretations devoted to Herbert's early poem "O Troi" ("On Troy") hastily refute the inevitable association of the debris field of what once was Troy with the Warsaw devastated in World War Two. ${ }^{38}$ The research on the later "Raport" does its best to emphasize that the siege is polysemous and that the association with martial law and the identification of the capitalized "Miasto" ("City") with Warsaw is too hasty. ${ }^{39}$ Andrzej Kaliszewski goes as far as detecting generalization as the main trope performed in Herbert's poems, ${ }^{40}$ and Adam Michnik states: "Herbert brought the ability to clothe the concrete in formulas of universal scope to perfection."

And indeed: the referents of the terms for victims in Herbert's poems oscillate between $\mathrm{Mr}$ Cogito and the author, between Polish and world history. Nevertheless, the binary constitution of an in-group in delineation from external besiegers prevails. This binary can be read not solely, but also, as Jerzy Kwiatkowski shows, ${ }^{42}$ as the "Polish archetype of being under siege" and therefore can also be inscribed in the Polish tradition of automartyrology:

\footnotetext{
${ }^{37}$ Michnik, "Potęga smaku," 263 and 280.

${ }^{38}$ Marlene BAINCZYK-CRESCEnTINI, "Mythos und Gegenwart. Die "Ilias" im lyrischen Werk Zbigniew Herberts," in Slavische Identitäten. Paradigmen, Poetiken, Perspektiven, ed. Gernot Howanitz, Christian Kampkötter, Heinrich Kirschbaum (München, Berlin, Washington, D.C.: Otto Sagner, 2014), 113-125, here p. 119.

${ }^{39}$ ŁUKASIEWICZ, Poez.ja Zbigniewa Herberta, 92; ADAMIEC, "Pomnik trochę niezupetny...," 117-119.

${ }^{40}$ KALISZEWSKI, Gry Pana Cogito, 79 and 93-94.

${ }^{41}$ MichNiK, "Potęga smaku," 254: "Herbert doprowadził do perfekcji umiejętność przyoblekania konkretu w formuły o nośności uniwersalnej."

42 JERZY KWIATKOWSKI, "Polski archetyp oblężenia. Historia-Sienkiewicz-MrożekHerbert," in Magia poezji (O poetach polskich XX wieku) (Kraków: Wydawnictwo Literackie, 1995), 391-405, here pp. 400-401.
} 
Odkryjemy w nim [w „Raporcie”] tradycyjny, patriotyczny palimpsest nakazujący złożyć w ofierze życie dla świętej sprawy ojczyzny, odczytamy także imperatyw obrony narodowych imponderabiliów [...]. ${ }^{43}$

In it [in Herbert's poem "Raport"] we recognize the traditional, patriotic palimpsest which compels us to sacrifice our lives for the holy sake of the fatherland. We also discern the imperative of defending the national imponderables [...].

\section{THE POLISH PEOPLE'S REPUBLIC AS SOVIET COLONYZATION}

To what degree, however, does Herbert in his antiquity allegories equate "them," the perpetrators, with the communist system imposed by the Soviet Union? Unequivocal references to communism and the People's Republic are rather rare, for example the aforementioned "Lenin jacket" and "Aurora's grandchildren" or "niebiescy proletariusze" ("the heavenly proletarians"). ${ }^{44}$ Who actually "put on the Poles" communism is often rendered metonymically—on a detour via the "predators" of Yalta who "extradited" Poland to a nameless other, "the Russians":

[...] nas zdradzili ich ojcowie / nasi byli alianci z czasów drugiej Apokalipsy

[...] their fathers betrayed us / our former allies at the time of the second Apocalypse $^{45}$

With this narrowing down of a wrong inflicted from outside to the results of the Yalta conference from February $1945^{46}$ the "we" can be unmistakably determined as Polish.

In Herbert's sarcastic invitation to an "invader" titled "17 IX." ("September 17") it is the possessive pronoun in combination with "ojczyzna" ("country," literally: "fatherland") that provides the national group identification:

\footnotetext{
${ }^{43}$ Jan PROKOP, "Raport z oblężonego Miasta po dwudziestu latach," in Herbert i znaki czasu. Colloquia Herbertiana (I), ed. Elżbieta Feliksiak, Mariusz Leś, Elżbieta Sidoruk (Białystok: Towarzystwo Literackie im. Adama Mickiewicza, Oddział Białostocki, 2001), 191-200, here p. 192.

${ }^{44}$ Herbert, Poezje / Gedichte, 48; Herbert, The Collected Poems 1956-1998, 240, trans. Alissa Valles.

${ }^{45}$ Herbert, Poezje wybrane / Selected Poems, 151, trans. John and Bogdana Carpenter.

${ }^{46}$ Vgl. Marta FIK, Kultura polska po Jatcie. Kronika lat 1944-1981 (London: Polonia, 1989).
} 
Moja bezbronna ojczyzna przyjmie cię najeźdźco

My defenseless country will welcome you invader ${ }^{47}$

The vocative singular "najeźdźco" determines the historical context as September 17, 1939, the day of the Soviet invasion of Poland, which came in fulfillment of the Molotov-Ribbentrop pact. Even if the Soviet invasion is merely a secondary consequence of the German attack on Poland from September 1, 1939, the "aggressor" in the singular is clearly Stalin here. ${ }^{48}$

In contrast to this unmistakable referentiality, the language of propaganda evoked in "Potęga smaku" ("The Power of Taste") only indirectly alludes to Russian-language communist propaganda; the interpretation that the statistically less frequent use of the subjunctive might denote Russian-in negative comparison to Polish - must be accomplished by the reader. The reference to the Iron Curtain in "Pan Cogito-powrót" ("Mr Cogito-the Return") seems highly obvious:

widzi już / granicę / zaorane pole / mordercze wieże strzelnicze / gęste zarośla drutu

he sees already / the frontier / a ploughed field / murderous shooting towers / dense thickets of wire ${ }^{49}$

This, however, does not directly affect a Polish border, but the innerGerman one from 1963 to 1989. In these two cases the concrete agents - the speakers of propaganda and the border guards-disappear behind the grammatical term "subjunctive" and the synecdoche of border fences, "thickets of wire."

The poem "Przesłuchanie anioła" ("Preliminary Investigation of an Angel") recalls the Soviet show trials of the 1930s with their extorted confessions, zooming into the perspective of a single accused:

jakże piękna jest chwila / gdy pada na kolana / wcielony w winę / nasycony treścią // język waha się/ między wybitymi zębami / a wyznaniem

\footnotetext{
${ }^{47}$ Herbert, Raport z oblężonego miasta, 85; Herbert, The Collected Poems 1956-1998, 403, trans. Alissa Valles.

${ }^{48}$ Adam Michnik regards this poem, which was written on September 17, 1981, as an anticipation of the declaration of martial law of December 13, 1981; in September 1981, a new Soviet invasion seemed imminent, see: МiсHNIK, "Potęga smaku," 26.

${ }^{49}$ Herbert, Poezje wybrane / Selected Poems, p. 105, trans. John and Bogdana Carpenter.
} 
how beautiful is the moment / when he falls on his knees / incarnate into guilt / saturated with contents // his tongue hesitates / between knocked-out teeth / and confession $^{50}$

Another "torture poem" with an ancient background, "Damastes z przydomkiem Prokrustes mówi" ("Damastes [also Known as Procrustes] speaks"), can be interpreted as an allegory on the brutal equalization projects of communism: the mythical Procrustes stretches his many victims on the proverbial Procrustean bed or chops off protruding limbs: "nie ustawałem w wysiłkach aby zrównać ludzi" ("I never stopped in my efforts to make people equal"). ${ }^{51}$

Against this backdrop, in the prose miniature "Cesarz" ("Emperor") the eponymous singular reads as an allegorical hint at Stalin:

Był sobie raz cesarz. [...] Najbardziej lubił polowania i terror. Ale fotografował się z dziećmi wśród kwiatów. Kiedy umarł, nikt nie śmiał zdjąć jego portretów.

Once upon a time there was an Emperor. [...] Most of all he liked hunting game and terror. But he posed for photographs with children and flowers. When he died, nobody dared to remove his portraits. ${ }^{52}$

The personal name Stalin is not mentioned, however, which preserves a certain suspension of reference.

The same goes for Herbert's use of the plural in contexts of power: he mostly avoids an explicit preliminary fixing of Poles, Russian or Soviets. The allegorical identification of the subalterns of the Roman Empire such as Hirpins, Apuleans, and Lucanians with Poles or of barbaric tribes coming from the East such as Longobards ("The Longobards") or Goths with the Soviets must be accomplished by the reader; the author bears only partial responsibility for this allegorical interpretation. In sum, communism appears more as a system than the concrete person of Stalin as an agent of aggression and repression, and Poland is evoked rather allegorically or metonymically as a collective victim.

\footnotetext{
${ }^{50}$ Herbert, Poezje wybrane / Selected Poems, 44-47, trans. John and Bogdana Carpenter.

${ }^{51}$ Herbert, Wiersze zebrane, p. 491; Herbert, Poezje wybrane / Selected Poems, 143, trans. John and Bogdana Carpenter.

${ }^{52}$ Herbert, Wiersze zebrane, 212; ZBigniew Herbert, The Collected Poems 1956-1998, 143-144, trans. Alissa Valles.
} 


\title{
6. SELF-COLONIZATION IN THE POLISH PEOPLE'S REPUBLIC
}

This means that the focus must be shifted away from the numeri applied to appellatives and pronouns designating perpetrators and victims to the processes of subjugation under communist rules of behavior and speech. The latter are represented via verb phrases: what does the political-cultural violence $^{53}$ imposed externally by the Soviet Union, but executed internally by Polish communists do to its victims? The victims internalize the imposed political culture; it is they who turn foreign colonization into self-colonization. An especially drastic allegory of self-colonization is provided in Herbert's poem "Powrót prokonsula" ("The Return of the Proconsul"). The nameless singular returner reflects upon the way in which he will have to adapt to the repressive system of his country of origin and to disguise his true feelings again:

\begin{abstract}
trzeba będzie na nowo ułożyć się z twarzą / z dolną wargą by umiała powściągnąć pogardę / z oczami aby były idealnie puste / i z nieszczęsnym podbródkiem zającem mej twarzy / który drży gdy wchodzi dowódca gwardii

I must come to terms with my face again / with my lower lip so it knows how to curb its scorn / with my eyes so they remain ideally empty / and with that miserable chin the hare of my face / which trembles when the Chief of guards walks in ${ }^{54}$
\end{abstract}

The impersonal modal verb "trzeba będzie" ("I must come," literally: "One has to") indicates how the individual diverts attention from his own consternation in a schizoid way. The collective cultural technique of selfsubordination is also detected in Cato's Utica:

obywatele / nie chcą się bronić / uczęszczają na przyspieszone kursy / padania na kolana

the citizens / don't want to defend themselves / they are attending accelerated courses / on falling to the knees ${ }^{55}$

Residual expressions of non-consent are banned from the public sphere; everyone is alone with his/her non-agreement:

\footnotetext{
${ }^{53}$ Vgl. Michnik, "Potęga smaku," 213.

${ }^{54}$ Herbert, Poezje wybrane / Selected Poems, 31, trans. Czesław Miłosz.

55 "Pan Cogito o postawie wyprostowanej" ("Mr Cogito on Upright Attitudes"), in Herbert, Poezje wybrane / Selected Poems, 89, trans. John and Bogdana Carpenter.
} 
Prometeusz śmieje się cicho. / Jest to teraz jego jedyny sposób wyrażenia niezgody na świat

Prometheus chuckles to himself. / This is now his only way of expressing his quarrel with the world. ${ }^{56}$

\section{INTERNALIZATION OF EXTERNAL COLONIAL RELATIONS}

In Herbert's poems, especially those contributing to his rewriting of antiquity from the 1970s and 80s, the relations between perpetrators and victims are transferred from international relations to the inner realm of a society and the inner world of the adapting subjects, which allows an allegorical reading with regard to the Polish People's Republic. Given this mechanism of internalization, the question arises which model of internal colonization allows one to grasp Herbert's binary of perpetrators that come from the outer world but appear in the inner world, and their collective or individual victims.

Models of internal colonization were proposed most prominently for the United Kingdom and Ireland ${ }^{57}$ and Russia, ${ }^{58}$ but were also partially adopted in Polish Studies. ${ }^{59}$ The topical Russian cultural studies consider also processes of self-colonization. ${ }^{60}$

The political reality of the Polish People's Republic is scrutinized in the postcolonial research initiatives undertaken by Ewa Domańska, Anna Artwińska, and Małgorzata Mikołajczak. ${ }^{61}$ While Domańska postpones the

\footnotetext{
56 "Stary Prometeusz" ("Old Prometheus"), in ZBigniew Herbert, Pan Cogito (Wrocław: Wydawnictwo Dolnośląskie, 1994), 60; Herbert, The Collected Poems 1956-1998, 309, trans. Alissa Valles.

${ }^{57}$ Michael Hechter, Internal Colonialism: The Celtic Fringe in British National Development, 1536-1966 (London: Routledge \& Kegan Paul, 1975).

${ }^{58}$ Alexander ETKIND, Internal Colonization: Russia's Imperial Experience (Cambridge: Polity, 2011).

${ }^{59}$ Michał Buchowski, "The Specter of Orientalism in Europe: From Exotic Other to Stigmatized Brother," in Anthropological Quarterly 79, no 3 (2006): 463-482, here p. 479 footnote 10; Tomasz ZARYCKI, "Polska i jej regiony a debata postkolonialna," in Oblicze polityczne regionów Polski, ed. Małgorzata Dajnowicz (Białystok: Wydawnictwo Wyższej Szkoły Finansów i Zarządzania, 2008), 31-48, here pp. 37 and 41; Ewa THOMPSON, "A jednak kolonializm. Uwagi epistemologiczne," in Teksty Drugie 6 (2011): 289-301, here p. 290.

${ }^{60}$ For this see: Dirk UfFelmann, "Podvodnye kamni vnutrennei (de)kolonizatsii Rossii," in Tam, vnutri. Praktiki vnutrennei kolonizatsii v kul'turnoi istorii Rossii, ed. Aleksandr Etkind, Dirk Uffelmann, Il'ia Kukulin (Moskva: Novoe literaturnoe obozrenie, 2012), 53-104.

${ }^{61}$ Ewa DomańsKa, "Obrazy PRL w perspektywie postkolonialnej. Studium przypadku," in Obrazy PRL. O konceptualizacji realnego socjalizmu w Polsce, ed. Krzysztof Brzechczyn (Poznań:
} 
fundamental question of whether Poland was colonized by the USSR, ${ }^{62}$ and Artwińska approaches it from post-socialist retrospectives, Mikołajczak, with her focus on Polish regional literature from the times of communism, comes closest to a description of the external-internal mechanisms of colonization which I endeavor to demonstrate for Zbigniew Herbert: for the times of the Polish People's Republic Mikołajczak speaks of a "situation of double colonization: by the culture of the Polish People's Republic, which again depended on the Soviet hegemon (and his cultural policy)." ${ }^{, 63}$ According to her, the former produced a landscape of a "'self-colonizing culture'." 64

Another researcher sensitive to postcolonial theory, Tomasz Zarycki, places the thesis of a Soviet colonization of the Polish People's Republic with correspondingly negative repercussions for internal mentalities on the right of the political spectrum. ${ }^{65}$ Such a nationalist instrumentalization of concepts of colonialism has been promoted by the figurehead of the intellectual right, Ewa Thompson. She defends her choice of the term "colonialism" for the Polish People's Republic with the fact that between 1945 and 1989 important decisions were not made in Warsaw, but in Moscow and that Soviet rule was introduced and maintained with the help of violence. ${ }^{66}$ Thompson contrasts the detested communist state with its victim that she identifies as the Polish nation. ${ }^{67}$ If we are to believe Thompson, the internal cultural effect of state-imposed pressure was a self-colonizing intellectual nation: "In the years 1945-1989 Polish intellectual discourse was the discourse of a colonized nation." $" 68$

Instytut Pamięci Narodowej, Komisja Ścigania Zbrodni Przeciwko Narodowi Polskiemu, Oddział w Poznaniu, 2008), 167-187; Anna ARTwiŃSKA, “Kompleks polski. Krytyka postkolonialna a PRL," in Opowiedzieć PRL, ed. Katarzyna Chmielewska, Grzegorz Wołowiec (Warszawa: Instytut Badań Literackich PAN, 2011), 33-48; Małgorzata MiKOŁAJCZAK, "Między mimikrą a rebelią. Pejzaż (post)kolonialny regionalnej literatury,” in Teksty Drugie 5 (2015): 283-305.

${ }^{62}$ DOMAŃSKA, “Obrazy PRL,” 169.

${ }^{63}$ MikOŁAJCZAK, "Między mimikrą a rebelią,” 287: "sytuacj[a] podwójnego skolonizowania: przez kulturę PRL-u, zależną od (polityki kulturalnej) sowieckiego hegemona."

${ }^{64}$ Ibidem, 288: "pejzaż 'samokolonizującej się kultury'."

${ }^{65}$ ZARYCKI, "Polska i jej regiony," 41.

${ }^{66}$ THOMPSON, “A jednak kolonializm,” 294.

${ }^{67}$ For the binary of state (=perpetrator) vs. people/nation (=victim) as a pattern constitutive for nationalist appropriations of postcolonial categories-not only in Poland-see Dirk Uffelmann, "Postcolonial Theory as Post-Colonial Nationalism," in Postcolonialism CrossExamined: Envisioning New Relations to the Colonial Past and Postcolonial Future, ed. Monika Albrecht (London: Routledge, 2019), 135-152, here pp. 138-139.

${ }^{68}$ THOMPSON, "A jednak kolonializm," 295: "W latach 1945-1989 polski dyskurs intelektualny był dyskursem skolonizowanego narodu." (emphasis in the original). 
Herbert's conceptualization of the Polish People's Republic is equally centered around internal political culture. His allegories of antiquity do not so much externalize communism as Soviet occupation (via Orientalization of Russians), as they explore the internal dynamics in the Polish People's Republic. Thus imbalance in power is highlighted as external-internal colonization. The political censorship in the Polish People's Republic prevented any explicit accusation of the Soviet Union as an external colonizer in print-and Herbert did not dare that either. ${ }^{69}$ As a consequence, the psychological effects of internal or self-colonization were a taboo, too. They were, however, expressed in Herbert's allegories of antiquity. My thesis is that Herbert's focus on internal and micro-politics connects the communist regime of the Polish People's Republic, as it was imposed from outside, with the "internal colonialization" (sic) of the lived-in world in the sense of Jürgen Habermas. ${ }^{70}$

\section{NATIONALIST INTERPRETATION \\ OF SOVIET EXTERNAL-INTERNAL COLONIZATION}

After the end of the limitations of communist censorship a certain rightwing and nationalist tendency in the adoption of postcolonial theory in Poland more explicitly envisaged the external colonizer whom Herbert could investigate only in the disguise of antiquity and from the perspective of internal dynamics. Especially Ewa Thompson conceptualizes communism as communist occupation. By doing so she explicates the nationalist rejection of external-internal colonization, which only appeared encapsulated in Herbert's metaphors of siege in antique allegories.

My final thesis is: nationalist appropriations of postcolonial theory may be problematic from the point of view of the critical potential of postcolonial studies. ${ }^{71}$ For describing Herbert's antique allegories of internal colonization of the political culture in the time of the Polish People's Republic they can, however, be highly appropriate as a heuristic analogy. From this analogy I conclude that in Herbert, as suggested by Piotr Lachmann, one can

\footnotetext{
${ }^{69}$ In this regard I disagree with Stanisław Barańczak's much too optimistic view of Herbert as a poet entirely free of self-censorship, cf. BARAŃCZAK, Uciekinier z utopii, 18 and 25.

70 "innere Kolonialisierung” (Jürgen HABERMAS, Theorie des kommunikativen Handelns, Bd.

2. Zur Kritik der funktionalistischen Vernunft (Frankfurt/M.: Suhrkamp, 1995), 523).

${ }^{71}$ Cf. Uffelmann, "Postcolonial Theory as Post-Colonial Nationalism," 142.
} 
diagnose a defensive nationalism, which in no way, as Jerzy Kwiatkowski argues, is the opposite of nationalism. ${ }^{72}$

To be sure: only in some of Herbert's poems are the victims presented as a collective, and they are Polonized only indirectly; Polish victims and Soviet perpetrators (among others, Stalin) are draped in the disguise of antique allegories. What is more, they are made digestible by Herbert's mischievous and seemingly naïve tone; they appear in an ironic light and are deprived from all-too obtrusive historical disambiguation. If we paraphrase Baranczak's thesis of the "among others" political meanings of Herbert's poems, we may, however, detect among others defensive nationalism in the antique disguise and with the potential meaning of an allegory on Poland's externalinternal colonization by the Soviet Union.

\section{BIBLIOGRAPHY}

ADAMIEC, Marek. “Pomnik trochę niezupetny...” Rzecz o apokryfach i poezji Zbigniewa Herberta (,A Monument a Little Incomplete...”: On Apocrypha and Zbigniew Herbert's Poetry. Gdańsk: Wydawnictwo Uniwersytetu Gdańskiego, 1996.

ARTWIŃSKA, Anna. "Kompleks polski. Krytyka postkolonialna a PRL" (The Polish Syndrome: Postcolonial Critique and the Polish People's Republic). In Opowiedzieć PRL (To Tell About the PRL), ed. Katarzyna Chmielewska, Grzegorz Wołowiec, 33-48. Warszawa: IBN, 2011.

AshCRoft, Bill, Gareth Griffiths, Helen Tiffin. The Empire Writes Back: Theory and Practice in Post-Colonial Literatures. London: Routledge, 1989.

BAincZyK-Crescentini, Marlene. "Mythos und Gegenwart. Die 'Ilias' im lyrischen Werk Zbigniew Herberts" (Myth and Present Age: The 'Iliad' in the Poetical Work of Zbigniew Herbert). In Slavische Identitäten. Paradigmen, Poetiken, Perspektiven (Slavic Identities: Paradigms, Poetics, and Perspectives), ed. Gernot Howanitz, Christian Kampkötter, Heinrich Kirschbaum, 113-125. Munich-Berlin-Washington, D. C.: Sagner, 2014.

BARAŃCZAK, Stanisław. Uciekinier z utopii. O poezji Zbigniewa Herberta (A Fugitive from Utopia: The Poetry of Zbigniew Herbert). London: Polonia, 1984.

BigaJ, Jan. "Za przesłaniem Herberta nie pójdę” (I Will Not Follow Herbert's Legacy). In Herbert. Poetyka, wartości i konteksty (Herbert: Poetics, Values, and Contexts), ed. Eugeniusz Czaplejewicz, Witold Sadowski, 165-172. Warszawa: DiG, 2002.

BuchowsKi, Michał. "The Specter of Orientalism in Europe: From Exotic Other to Stigmatized Brother." Anthropological Quarterly 79, nr 3 (2006): 463-482.

DomańSKA, Ewa. "Obrazy PRL w perspektywie postkolonialnej. Studium przypadku” (Depictions of the Polish People's Republic from a Postcolonial Perspective: A Case Study). In Obrazy PRL. O konceptualizacji realnego socjalizmu $w$ Polsce (Pictures of the Polish

\footnotetext{
72 KwiATKOwSKI, "Polski archetyp oblężenia," 405: “[...] patriotyzm obronny, ten, który jest przeciwieństwem nacjonalizmu."
} 
People's Republic: On the Conceptualization of Real Socialism in Poland), ed. Krzysztof Brzechczyn, 167-187. Poznań: IPN, 2008.

ETKIND, Alexander. Internal Colonization: Russia's Imperial Experience. Cambridge: Polity, 2011.

FIK, Marta. Kultura polska po Jatcie. Kronika lat 1944-1981 (Polish Culture After Yalta: A Chronicle of the Years 1944-1981). London: Polonia Book Fund, 1989.

HABERMAS, Jürgen. Theorie des kommunikativen Handelns (The Theory of Communicative Action), vol. II, Zur Kritik der funktionalistischen Vernunft (A Critique of Functionalist Reason). Frankfurt/M.: Suhrkamp, 1995.

Hechter, Michael. Internal Colonialism: The Celtic Fringe in British National Development, 1536-1966. London: Routledge \& Kegan Paul, 1975.

Herbert, Zbigniew. Poezje / Gedichte, ed. Karl Dedecius. Kraków: Wydawnictwo Literackie, 2007.

Herbert, Zbigniew. Poezje wybrane / Selected Poems, trans. John and Bogdana Carpenter, Czesław Miłosz, and Peter Dale Scott. Kraków: Wydawnictwo Literackie, 1999.

HERBERT, Zbigniew. Raport z oblężonego miasta. Wrocław: Wydawnictwo Dolnośląskie, 1995.

Herbert, Zbigniew. Struna światta. Wrocław: Wydawnictwo Dolnośląskie, 1994.

Herbert, Zbigniew. Studium przedmiotu. Wrocław: Wydawnictwo Dolnośląskie, 1997.

Herbert, Zbigniew. The Collected Poems 1956-1998, ed. Alissa Valles. New York: Ecco, 2007.

Herbert, Zbigniew. Wiersze zebrane (Collected Poems), ed. Ryszard Krynicki. Kraków: Wydawnictwo A5, 2008.

Herlth, Jens. "Wer sind Herberts Barbaren?“" (Who Are Herbert's Barbarians?). In Herr Cogito im Garten. Zbigniew Herbert (Mr Cogito in the Garden: Zbigniew Herbert), ed. Andreas Lawaty, Piotr Przybyła, Marek Zybura, 135-151. Osnabrück: Fibre, 2018.

Hingley, Richard. "Post-Colonial and Global Rome: The Genealogy of Empire." In Globalisation and the Roman World: World History, Connectivity and Material Culture, ed. Martin Pitts, Miguel J. Versluys, 32-46. Cambridge: Cambridge University Press, 2015.

JAKOBSOn, Roman. "Poetry of Grammar and Grammar of Poetry." In Selected Writings, vol. III, 87-97. Den Haag, Paris: De Gruyter, 1980.

JAKOBSON, Roman. "Poezija grammatiki i grammatika poezii" (Poetry of Grammar and Grammar of Poetry). In Selected Writings, vol. III, 63-86. Den Haag, Paryż: De Gruyter, 1980.

JANION, Maria. Niesamowita stowiańszczyzna (The Uncanny Slavdom). Kraków: Wydawnictwo Literackie, 2007.

KaliszewsKi, Andrzej. Gry Pana Cogito (Mr. Cogito’s Games). Łódź: Wydawnictwo Łódzkie, 1990.

KornHAUSER, Julian. "Herbert: z odległej prowincji" (Herbert: From Faraway Provinces). In Kornhauser, Julian, Adam ZAGAJEWSKI. Świat nie przedstawiony (The Unrepresented World), 100-109. Kraków: Wydawnictwo Literackie, 1974.

KowalczyK, Andrzej. "Złote runo nicości” (The Golden Fleece of Nothingness). Tygodnik Powszechny 11 (1983): 4.

KwiATKOWSKI, Jerzy. "Polski archetyp oblężenia. Historia—Sienkiewicz-Mrożek—Herbert" (The Polish Archetype of Siege: History—Sienkiewicz-Mrożek-Herbert). In Magia poezji (O poetach polskich XX wieku) (The Magic of Poetry: Polish Poets of the 20 ${ }^{\text {th }}$ Century), 391-405. Kraków: Wydawnictwo Literackie, 1995.

LACHMANN, Piotr. Wywołane z pamięci (Retrieved from Memory). Olsztyn: Borussia 1999. 
ŁukASIEwICZ, Jacek. Poezja Zbigniewa Herberta (Zbigniew Herbert's Poetry). Warszawa: Wydawnictwa Szkolne i Pedagogiczne, 1995.

Mattingly, David J. Imperialism, Power, and Identity: Experiencing the Roman Empire. Princeton (NJ), Oxford: Princeton University Press, 2011.

Michnik, Adam. "Potęga smaku" (The Power of Taste). In Z dziejów honoru w Polsce (A History of Honor in Poland), 199-280. Paris: Institut Littéraire, 1985.

MikoŁajczaK, Małgorzata. "Między mimikrą a rebelią. Pejzaż (post)kolonialny regionalnej literatury" (Between Mimicry and Rebellion: The (Post-)Colonial Landscape of Regional Literature). Teksty Drugie nr 5 (2015): 283-305.

PROKOP, Jan. "Raport z oblężonego Miasta po dwudziestu latach" (Report from a Besieged City Twenty Years Later). In Herbert i znaki czasu. Colloquia Herbertiana (I) (Herbert and the Signs of the Time: Colloquia Herbertiana [I]), ed. Elżbieta Feliksiak, Mariusz Leś, Elżbieta Sidoruk, 191-200. Białystok: Towarzystwo Literackie im. A. Mickiewicza Oddział Białostocki, 2001.

PRZYBYLSKI, Ryszard. "Między cierpieniem a formą" (Between Suffering and Form). In To jest klasycyzm (This Is Classicism), 124-175. Warszawa: Czytelnik, 1978.

Roman Imperialism: Post-Colonial Perspectives. Proceedings of a Symposium Held at Leicester University in November 1994, ed. Jane Webster, Nicholas J. Cooper. Leicester: School of Archaeological Studies, University of Leicester, 1996.

SCHMID, Ulrich. "Nach dem Kommunismus. Herberts politische Interventionen in der Dritten Republik" (After Communism: Herbert's Political Interventions in the Third Republic). In Herr Cogito im Garten. Zbigniew Herbert (Mr Cogito in the Garden: Zbigniew Herbert), ed. Andreas Lawaty, Piotr Przybyła, Marek Zybura, 191-200. Osnabrück: Fibre, 2018.

SKóRCZEWSKI, Dariusz. Teoria-literatura-dyskurs. Pejzaż postkolonialny (Theory-Literature-Discourse: The Postcolonial Landscape). Lublin: Wydawnictwo KUL, 2013.

TerrenAto, Nicola. "The Deceptive Archetype: Roman Colonialism in Italy and Postcolonial Thought." In Ancient Colonizations: Analogy, Similarity and Difference, ed. Henry Hurst, Sara Owen, 59-72. Londyn: Duckworth, 2005.

ThOmpson, Ewa. "A jednak kolonializm. Uwagi epistemologiczne" (It Is Colonialism After All: Some Epistemological Remarks). Teksty Drugie nr 6 (2011): 289-301.

Thompson, Ewa. "Nationalism, Imperialism, Identity: Second Thoughts." Modern Age 40, nr 3 (1998): 250-261.

TrochA, Bogdan. "Mythopoeiczne aspekty liryki Zbigniewa Herberta" (Mythopoeic Aspects of Zbigniew Herbert's Poetry). In Pojęcia kietkujące z rzeczy. Filozoficzne inspiracje twórczości Zbigniewa Herberta (Notions Germinating from Things: The Philosophical Inspirations of Zbigniew Herbert's Works), ed. Józef M. Ruszar, 101-137. Kraków: Wydawnictwo Platan, 2010.

UfFelmann, Dirk. “Autobiografizm i antropologia. 'Ecce Homo' F. Nietzschego i 'Pan Cogito' Z. Herberta" (Autobiography and Anthropology: Friedrich Nietzsche's 'Ecce Homo' and Zbigniew Herbert's 'Mr. Cogito'). In Postać literacka (The Literary Character), ed. Edward Kasperski, Brygida Pawłowska-Jądrzyk, 53-75. Warszawa: Uniwersytet Warszawski, 1998.

UfFelmann, Dirk. "Podvodnye kamni vnutrennei (de)kolonizatsii Rossii" (The Pitfalls of Russia's Internal (De-)Colonization). In Tam, vnutri. Praktiki vnutrennei kolonizatsii v kul'turnoi istorii Rossii (There within: Practices of Internal Colonization in Russia's Cultural History), 
ed. Aleksandr Etkind, Dirk Uffelmann, Il'ia Kukulin, 53-104. Mosvka: Novoe literaturnoe obozrenie, 2012.

Uffelmann, Dirk. "Postcolonial Theory as Post-Colonial Nationalism." In Postcolonialism Cross-Examined: Envisioning New Relations to the Colonial Past and Postcolonial Future, ed. Monika Albrecht, 135-152. London: Routledge, 2019.

Van Dommelen, Peter A.R. On Colonial Grounds: A Comparative Study of Colonialism and Rural Settlement in First Millennium BC West Central Sardinia. Leiden: University of Leiden, 1998.

ZARYCKI, Tomasz. "Polska i jej regiony a debata postkolonialna" (Poland, Its Regions, and the Postcolonial Debate). In Oblicze polityczne regionów Polski (The Political Countenance of the Polish Regions), ed. Małgorzata Dajnowicz, 31-48. Białystok: Wydawnictwo Wyższej Szkoły Finansów i Zarządzania, 2008.

\section{HERBERT’S POSTCOLONIAL ANTIQUITY AND DEFENSIVE NATIONALISM}

\section{Summary}

This paper proposes a postcolonial reading of antiquity motifs from Zbigniew Herbert's poems from the times of socialism. References to ancient history, mythology, and biblical allusions are interpreted as allegories of the political culture in the Polish People's Republic. While in his poems written between 1956 and 1990 Herbert depicts communism as an attempt at Russian colonization of Poland, in seminal texts the focus lies mainly on the internal effects for the Polish colonized mind.

Linking communist Moscow to ancient Rome, Herbert accomplishes a peculiar anti-imperial translatio imperii. It is this trans-chronic perspective of Herbert's poems which allows for rounding off the paper with connecting Herbert's anti-imperial attitude with defensive nationalism and proposing recent right-wing tendencies in the Polish appropriation of post-colonial theory (Ewa Thompson et al.) as a heuristic model for understanding Herbert's civil position during communism.

Key words: Zbigniew Herbert; poetry; antiquity; Polish People's Republic; postcolonialism; nationalism; internal colonization.

The preparation of the English version of Roczniki Humanistyczne (Annals of Arts) and its publication in electronic databases was financed under contract no. 836/P-DUN/2018 from the resources of the Minister of Science and Higher Education for the popularization of science. 